\title{
Suppression of Fusarium solani f. sp. phaseoli on Bean by Aluminum in Acid Soils
}

\author{
Hiromitsu Furuya, Tadashi Takahashi, and Tsutomu Matsumoto
}

Department of Agriculture, Akita Prefectural College of Agriculture, Ogata, Akita, 010-0444, Japan.

Accepted for publication 28 September 1998.

\begin{abstract}
Furuya, H., Takahashi, T., and Matsumoto, T. 1999. Suppression of Fusarium solani f. sp. phaseoli on bean by aluminum in acid soils. Phytopathology 89:47-52.

The severity of bean root rot caused by Fusarium solani f. sp. phaseoli in vitro was studied with regard to exchangeable soil aluminum for 25 soil samples collected from northeastern Honshyu island, Japan. Of these, 24 were Andosols, typically acidic and of volcanic ash origin. Disease severity was assessed based on the number of lesions produced by the pathogen on a 6-cm section of bean stem buried and incubated for 8 days at $25^{\circ} \mathrm{C}$

was very low, macroconidial germination was strongly inhibited. The inhibition was observed in all soil samples with exchangeable aluminum contents of at least $0.4 \mathrm{meq} / 100 \mathrm{~g}$ of soil, although it is unclear if this concentration is the lowest limit for inhibition. When soil $\mathrm{pH}$ was 5.6 or lower, higher amounts of exchangeable aluminum were detected from soils in which the major clay mineralogy was chloritized 2:1 minerals, while no or limited amounts of aluminum were detected from soils in which the major clay mineralogy was allophane/imogolite. Macroconidial germination and disease incidence are thus closely related to clay mineralogy, which regulates the behavior of exchangeable aluminum.
\end{abstract} in artificially infested soil samples. The number of lesions differed considerably among soil samples. In all soils in which disease incidence
Additional keywords: allophanic Andosols, residual soil fungistasis.
On the basis of in vitro tests, several soilborne plant pathogens have been found to be very sensitive to aluminum including Aphanomyces euteiches Drechsler (17), Phytophthora capsici Leonian (21), Phytophthora parasitica Dastur (2), Verticillium albo-atrum Reinke \& Berthold (22), Rhizoctonia solani Kühn AG4 $(14,15)$, Thielaviopsis basicola (Berk. \& Broome) Ferraris (19), and Streptomyces scabies (Thaxter) Waksman et Henrici (20). Disease incidence caused by these pathogens may be suppressed by aluminum in natural soil $(8,15,19,20,22)$, by aluminum treatment of natural soil (17), or by aluminum treatment of an artificially prepared potting medium (2). The suppression of soilborne diseases by soil aluminum has been observed only in acid soil.

The nonpathogenic soil fungus Neurospora tetrasperma Shear \& Dodge (13) and saprophytic soil bacteria $(13,31,32)$ are inhibited by toxic levels of aluminum in soil. Soil aluminum may thus greatly affect the ecology not only of plant-pathogenic microorganisms, but also of nonpathogenic microorganisms in many acid soils (4). However, there have been only limited studies on the mechanisms of inhibition in natural soil. Most information has been obtained by in vitro experimentation or by using artificially prepared soil. Basic information on aluminum toxicity to microorganisms in natural soil (18) is still quite inadequate.

Root rot of kidney bean (Phaseolus vulgaris L.), caused by Fusarium solani (Mart.) Appel \& Wr. f. sp. phaseoli (Burk.) Snyd. et Hans., has been devastating in Hokkaido, Japan. A soil in the Kitami region of the island that suppresses the disease was reported (7) and is hereafter referred to as Kitami soil. Germination and chlamydospore production of macroconidia and growth and chlamydospore production of hyphae are strongly suppressed in this soil (7). Persistence of chlamydospores may not be inhibited, unless they germinate (7). Although it is not known whether chlamydospore germination is inhibited in the soil, it is easily conceivable that

Corresponding author: H. Furuya; E-mail address: furuya@swan.apca.ac.jp

Publication no. P-1998-1102-01R

(C) 1999 The American Phytopathological Society chlamydospores would fail to infect host plant roots, since growth of the germ tubes and hyphae from the chlamydospores may be inhibited in the soil. Furuya et al. (8) suggested that aluminum toxicity of the soil is a major cause of suppression of the pathogen and, hence, of disease incidence.

This study was conducted to obtain further evidence for the suppression of $F$. solani $\mathrm{f}$. sp. phaseoli by soil aluminum and to clarify the relationship between suppression and soil mineralogy and the distribution of suppressive soil.

\section{MATERIALS AND METHODS}

Collection and analysis of soil samples. A total of 25 soil samples was collected from 18 sites in Aomori, Akita, Iwate, Yamagata, and Miyagi prefectures in northeastern Honshu, the main island of Japan (Fig. 1). Sampling sites were all under natural vegetation adjacent to cultivated crop fields. Samples were air-dried soon after collection, ground to pass through a 2-mm mesh sieve, and stored in plastic bags at room temperature until used.

Soil $\mathrm{pH}$ was determined potentiometrically in distilled water (1:2.5, wt/vol). Maximum water-holding capacity (MWHC) was determined as the average moisture content of a disturbed sample of soil, $1 \mathrm{~cm}$ high, that is at equilibrium with a water table at its lower surface (1). Total carbon content was measured by dry combustion. Allophane and imogolite content were estimated by the formula of 7.14 multiplied by the amuont of acid-oxalate-extractable $\mathrm{Si}$, according to Parfitt (23). Major clay mineralogy was regarded as allophane/imogolite when the content was $>3.57 \%$ (25). Exchange acidity $\left(\mathrm{Y}_{1}\right)$ was determined by titration of $125 \mathrm{ml}$ of $1 \mathrm{M}$ $\mathrm{KCl}$ soil extract (100:250, wt/vol) with $0.1 \mathrm{M} \mathrm{NaOH}$ (26). Exchangeable $\mathrm{Al}^{3+}$ was calculated from exchange acidity based on the finding that acid substances in the $\mathrm{KCl}$ extract consist mainly of $\mathrm{Al}^{3+}$ ions (26).

Disease incidence in soil. Incidence was estimated based on the number of lesions on bean stem sections buried and maintained in soil infested with a virulent isolate of $F$. solani $\mathrm{f}$. sp. phaseoli (7). 
Macroconidia of the pathogen were harvested from 2-week-old potato dextrose agar slant cultures, rinsed with sterile distilled water three times, used to infest part of each soil sample at $10^{4}$ per $\mathrm{g}$ of dry soil, and mixed thoroughly. The infested samples, with water content adjusted to $50 \%$ of MWHC, were put into plastic containers ( 14 by 20 by $2 \mathrm{~cm}$ ). Bean stems ( $P$. vulgaris var. Taisho-Kintoki) were obtained by growing bean seedlings in the dark for 11 to 14 days at room temperature. The stems, which grew longer than $25 \mathrm{~cm}$ during culture, were harvested and trimmed to 10 -cm-long sections. Six bean sections were buried in infested soil of a plastic container; two replicate containers were used for each sample. Containers were incubated at $25^{\circ} \mathrm{C}$ for 8 days. The number of lesions longer than $1 \mathrm{~mm}$ that developed on the central $6-\mathrm{cm}$ of stem section during incubation was counted. When more than two lesions joined to produce one big lesion, lesions originating from separate infection sites were counted separately when possible. The mean number of the lesions per stem from 12 sections was obtained for each soil sample in an experiment and used as an indicator of disease severity. The infestation and assay experiment was repeated three times for each sample.

Stem sections were also buried and maintained, as described above, in original soil samples that had not been infested by the pathogen to determine if the samples were pathogen free.

Macroconidial germination in soil. Each soil sample was put in a petri dish (6 $\mathrm{cm}$ in diameter), moistened with sterile distilled water to about $60 \%$ MWHC (which is the field capacity for many soils), and covered with a circular sheet of cellophane film. Small air bubbles between the film and soil surface were squeezed out by forceps to ensure contact. The cellophane film was boiled several times in distilled water to remove surface coating material and sterilized by autoclaving prior to mounting on the soil surface (12). A 120- $\mu$ l aliquot of the macroconidial suspension $\left(10^{5}\right.$ spores per $\left.\mathrm{ml}\right)$ was pipetted and spread onto the film surface. Approximately 10 spores were seeded in a $1-\mathrm{mm}^{2}$ piece of film. After $48 \mathrm{~h}$ of incubation at $25^{\circ} \mathrm{C}$ in the dark, $1-\mathrm{cm}^{2}$ square of the film was cut out and spread on a water agar plate, and macroconidial germination on the film was examined with a microscope after staining with lactophenol cotton blue. More than 200 spores from each petri dish were observed to estimate the percentage of germination. The test was performed three times. In the first experiment, three replicate petri dishes for each soil sample were employed; two replicates were examined for the other two experiments.

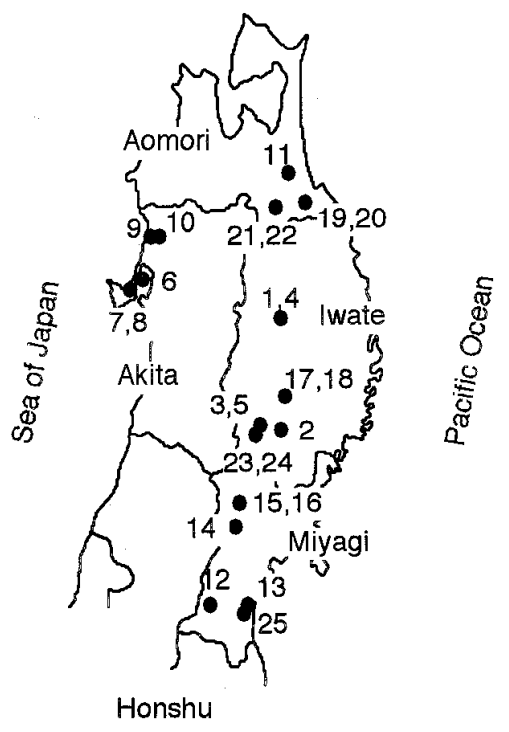

Fig. 1. Soil sampling sites and number of soil samples collected at each site.
Germination tests were also conducted in autoclaved soil samples to determine whether heat stable factors were involved in germination inhibition. Approximately $100 \mathrm{~g}$ of each soil sample was placed in a small glass beaker covered with a cotton plug and autoclaved for $20 \mathrm{~min}$ at $121^{\circ} \mathrm{C}$. The same technique as described above for tests with natural soils was also applied for tests with autoclaved soils. Three replicate petri dishes were used for each sample. The experiment was repeated three times.

Statistical analyses. Data on disease severity (mean numbers of the lesions per stem) were analyzed by a two-factor analysis of variance (ANOVA) with soil sample and experimental repetition (time) as the main factors. The repetition was not significant $(P=0.57)$; therefore, means from three experiments were pooled for analysis. However, the ANOVA showed significance for soil samples $(P<0.001)$; therefore, means were separated by Fisher's protected least significant difference procedure at $P=0.05$ with StatView J 4.5 (Abacus Concepts; StatView, Inc., Berkeley, CA).

When exchangeable aluminum, macroconidial germination, and disease severity were compared by soil $\mathrm{pH}$, exchangeable aluminum, or clay mineralogy, the significance of difference was assessed by Welch's $t$ test after checking for homogeneity of variance at $P=0.05$.

\section{RESULTS}

Physical and chemical properties of soil samples. All soil samples except \#6 were Andosols as characterized by volcanic ash origin and acidic behavior in reaction (Table 1). The $\mathrm{pH}$ of the Andosols ranged from 4.1 to 6.4. Every soil sample with a $\mathrm{pH}$ higher than 5.6 contained less exchangeable aluminum than

TABLE 1. Physical and chemical properties of soil samples

\begin{tabular}{|c|c|c|c|c|c|c|}
\hline $\begin{array}{l}\text { Soil } \\
\text { sample }\end{array}$ & $\begin{array}{c}\text { Allophane/ } \\
\text { imogolite } \\
(\%)^{\mathrm{v}}\end{array}$ & $\begin{array}{c}\text { Clay } \\
\text { mineralogy }\end{array}$ & $\begin{array}{c}\mathrm{pH} \\
\left(\mathrm{H}_{2} \mathrm{O}\right)\end{array}$ & $\begin{array}{l}\text { Exch. Al } \\
(\text { meq/ } \\
100 \mathrm{~g})^{\mathrm{x}}\end{array}$ & $\begin{array}{c}\text { Organic } \\
\text { carbon } \\
(\%)^{\mathrm{y}}\end{array}$ & $\begin{array}{c}\text { MWHC } \\
(\%)^{\mathrm{z}}\end{array}$ \\
\hline 1 & 26.1 & Allophanic & 6.4 & 0.2 & 2.4 & 164.1 \\
\hline 2 & 1.4 & Nonallophanic & 5.2 & 3.7 & 10.1 & 145.8 \\
\hline 3 & 0.6 & Nonallophanic & 5.2 & 10.0 & 2.8 & 59.1 \\
\hline 4 & 15.8 & Allophanic & 5.9 & 0.2 & 4.9 & 166.5 \\
\hline 5 & 27.4 & Allophanic & 5.8 & 0.1 & 0.5 & 94.2 \\
\hline 6 & 1.2 & Nonallophanic & 7.1 & 0.3 & 2.2 & 90.6 \\
\hline 7 & 7.4 & Allophanic & 5.3 & 1.9 & 1.8 & 104.8 \\
\hline 8 & 0.5 & Nonallophanic & 5.0 & 3.6 & 6.3 & 76.1 \\
\hline 9 & 0.8 & Nonallophanic & 5.1 & 3.7 & 7.6 & 94.9 \\
\hline 10 & 0.2 & Nonallophanic & 5.3 & 4.9 & 8.4 & 122.7 \\
\hline 11 & 6.2 & Allophanic & 5.4 & 0.5 & 7.1 & 117.4 \\
\hline 12 & 22.9 & Allophanic & 6.3 & Trace & 2.9 & 99.8 \\
\hline 13 & 1.1 & Nonallophanic & 6.2 & Trace & 0.2 & 87.7 \\
\hline 14 & 0.9 & Nonallophanic & 5.6 & 5.5 & 0.9 & 73.5 \\
\hline 15 & 1.1 & Nonallophanic & 4.2 & 4.2 & 14.3 & 156.9 \\
\hline 16 & 1.2 & Nonallophanic & 4.5 & 3.5 & 9.1 & 129.3 \\
\hline 17 & 0.9 & Nonallophanic & 4.1 & 5.2 & 8.4 & 134.8 \\
\hline 18 & 1.2 & Nonallophanic & 5.5 & 3.3 & 0.9 & 78.0 \\
\hline 19 & 6.4 & Allophanic & 4.9 & 0.4 & 7.5 & 127.0 \\
\hline 20 & 29.4 & Allophanic & 6.0 & Trace & 4.0 & 164.3 \\
\hline 21 & 3.6 & Allophanic & 5.6 & Trace & 4.7 & 126.6 \\
\hline 22 & 6.2 & Allophanic & 6.0 & Trace & 3.1 & 100.0 \\
\hline 23 & 0.9 & Nonallophanic & 4.2 & 6.5 & 12.1 & 173.3 \\
\hline 24 & 0.6 & Nonallophanic & 4.5 & 5.8 & 13.8 & 208.1 \\
\hline 25 & 20.7 & Allophanic & 5.7 & Trace & 0.3 & 104.7 \\
\hline
\end{tabular}

${ }^{v}$ The content was estimated by the formula of 7.14 multiplied by the amount of acid-oxalate-extractable $\mathrm{Si}$, according to Parfitt (23).

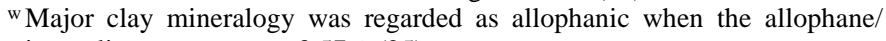
imogolite content was $>3.57 \%$ (25).

${ }^{x}$ Exchangeable $\mathrm{Al}$; the aluminum content was one-fifth of exchange acidity, which was determined by titration of $125 \mathrm{ml}$ of $1 \mathrm{M} \mathrm{KCl}$-soil extract (100:250, wt/vol) with $0.1 \mathrm{M} \mathrm{NaOH}(26)$.

y Total carbon was measured by dry combustion.

${ }^{\mathrm{z}}$ Maximum water-holding capacity (MWHC) was determined as the average moisture content of a disturbed sample of soil $1 \mathrm{~cm}$ high (1). 
$0.3 \mathrm{meq} / 100 \mathrm{~g}$ of soil, whereas samples with $\mathrm{pH} 5.6$ or lower generally contained very high amounts of exchangeable aluminum $(t=$ 6.025 , df $=15.1, P<0.001$ ) (Table 1 ). Of the 24 soil samples, 11 were grouped as allophanic Andosols, since their clay mineralogy was dominated by allophane/imogolite (Table 1) (25). Clay fractions of nonallophanic Andosols are dominated by chloritized 2:1 minerals, one of the phyllosilicate minerals, according to Shoji et al. (27). Allophanic soil samples contained little exchangeable aluminum, $1.9 \mathrm{meq} / 100 \mathrm{~g}$ of soil at the most, whereas nonallophanic samples contained $3.3 \mathrm{meq} / 100 \mathrm{~g}$ of soil or more $(t=5.862$, df $=14.7, P<0.001)$. Thus, more exchangeable aluminum was detected from nonallophanic than allophanic Andosols, as reported previously $(25,27,28)$. Soil sample \#6 was alluvial with a neutral reaction.

Disease incidence and macroconidial germination in soil samples. Preliminary tests showed that no lesions caused by $F$. solani f. sp. phaseoli developed on stems incubated in original soil samples, indicating that these soil samples were pathogen free unless artificially infested. Lesions caused by pathogens other than $F$. solani f. sp. phaseoli were rarely observed in stems throughout the experiment.

Disease severity in infested soil samples varied widely (Table 2). The number of lesions per 6-cm section of bean stem caused by $F$. solani $\mathrm{f}$. sp. phaseoli in 17 of the 25 soil samples was quite low, 1.1 or less. Macroconidial germination was less than $13 \%$ in these 17 samples. In six of the other eight soil samples, the mean number of lesions was at least 4.5. Numerous lesions, most of them overlapping, developed in soil sample \#22, and so lesion numbers could not be accurately determined, although more than 20 lesions

TABLE 2. Incidence of bean root rot caused by Fusarium solani f. sp. phaseoli and macroconidial germination of the fungus in soil samples

\begin{tabular}{lccc}
\hline & & \multicolumn{2}{c}{ Macroconidial germination $(\%)^{\mathrm{z}}$} \\
\cline { 3 - 4 } Soil sample & No. lesions ${ }^{\mathrm{y}}$ & Untreated soil & Autoclaved soil \\
\hline 1 & $4.5 \mathrm{c}$ & $99.7 \pm 0.3$ & 100 \\
2 & $0.2 \mathrm{a}$ & $0.3 \pm 0.3$ & 0 \\
3 & $0 \mathrm{a}$ & 0 & 0 \\
4 & $7.4 \mathrm{~d}$ & $97.3 \pm 1.5$ & 100 \\
5 & $0.3 \mathrm{a}$ & 0 & 0 \\
6 & $13.2 \mathrm{e}$ & $86.5 \pm 5.6$ & 100 \\
7 & $0.5 \mathrm{a}$ & $0.3 \pm 0.3$ & 0 \\
8 & $1.1 \mathrm{a}$ & $12.4 \pm 9.7$ & $99.5 \pm 0.5$ \\
9 & $0.8 \mathrm{a}$ & 0 & 0 \\
10 & $0.1 \mathrm{a}$ & 0 & 0 \\
11 & $0.7 \mathrm{a}$ & 0 & $56.4 \pm 3.3$ \\
12 & $3.1 \mathrm{bc}$ & $18.2 \pm 1.3$ & $12.4 \pm 3.3$ \\
13 & $6.2 \mathrm{~d}$ & $99.9 \pm 0.1$ & 100 \\
14 & $0.4 \mathrm{a}$ & 0 & 0 \\
15 & $0.6 \mathrm{a}$ & 0 & 0 \\
16 & $0.1 \mathrm{a}$ & 0 & 0 \\
17 & $0.3 \mathrm{a}$ & 0 & 0 \\
18 & $0.2 \mathrm{a}$ & 0 & 0 \\
19 & $0.8 \mathrm{a}$ & 0 & $85.9 \pm 3.0$ \\
20 & $2.6 \mathrm{~b}$ & $93.9 \pm 2.5$ & 100 \\
21 & $12.0 \mathrm{e}$ & $99.0 \pm 0.5$ & 0 \\
22 & $20 \mathrm{~g}$ & $99.6 \pm 0.4$ & 0 \\
23 & $0.2 \mathrm{a}$ & 0 & 0 \\
24 & $0.1 \mathrm{a}$ & 0 & 0 \\
25 & $0.4 \mathrm{a}$ & 0 & 0 \\
\hline
\end{tabular}

${ }^{y}$ Bean stem sections were buried and incubated for 8 days at $25^{\circ} \mathrm{C}$ in soil samples infested with macroconidia of $F$. solani f. sp. phaseoli at $10^{4}$ per $\mathrm{g}$ of dry soil. Lesions that developed on a 6-cm stem section were counted, and the mean number of lesions from 12 sections for each sample was obtained in one experiment. The experiment was performed three times for each sample. The data from repeated experiments were pooled for analysis, because experimental repetition was not significant at $P=0.57$ by a two-factor analysis of variance. Means followed by the same letter are not significantly different at $P=0.05$ according to Fisher's protected least significant difference.

${ }^{\mathrm{z}}$ Macroconidia were spread on cellophane film over the soil surface at approximately 10 per $\mathrm{mm}^{2}$ and incubated for $48 \mathrm{~h}$ at $25^{\circ} \mathrm{C}$. Means with standard errors were from three replicates in one of three experiments. were counted per stem. The data were not included in the analysis by the two-factor ANOVA. Macroconidial germination was very high, more than $80 \%$, in those six samples. Disease incidence in the other two soil samples (\#12 and \#20) was intermediate to the other two groups (Table 2). Macroconidial germination was fairly low in one (\#12), but fairly high in the other sample (\#20). Germ tube growth in the latter, however, was very poor compared with those in samples in which macroconidia readily germinated.

Apical cells of some macroconidia that were spread on the surface of some soils (i.e., \#8, \#11, \#18, and \#25) swelled to about twice the normal width of central cells of conidia. Some swollen cells lost their cytoplasm within $72 \mathrm{~h}$.

Macroconidial germination was also tested in autoclaved soil samples. Of the 18 soil samples in which germination was initially suppressed, germination was still very low in 16 samples after autoclaving (Table 2). In autoclaved soil sample \#12, germ tube growth was very poor, although some macroconidia germinated. Improvement in germination by autoclaving the soil was observed only in samples \#8 and \#11 (Table 2). Germ tube growth, however, was still very limited, and the tubes and hyphae showed thickening to almost that of the widest part of macroconidia and sporadically abnormal swelling in both soils.

In the other seven soil samples, in which macroconidia readily germinated in nonautoclaved samples, germination was still high after autoclaving except in soil sample \#20, in which germination was slightly reduced. Growth of germ tubes in the autoclaved soil sample was very poor.

Macroconidial germination in soil samples related to soil $\mathbf{p H}$ and exchangeable aluminum. Macroconidial germination was very low in 14 soil samples with a $\mathrm{pH}$ of 5.5 or lower and highly variable in the other 11 samples with $\mathrm{pH} 5.6$ or higher $(t=4.393$, df $=10.1, P=0.0013$ ) (Tables 1 and 2 ). Germination was rarely observed in the 15 soil samples with exchangeable aluminum contents of $0.4 \mathrm{meq} / 100 \mathrm{~g}$ of soil or more $(t=4.898, \mathrm{df}=9.1, P<0.001)$ (Tables 1 and 2). Germination also varied considerably in the other 10 soil samples with exchangeable aluminum of $0.3 \mathrm{meq} / 100 \mathrm{~g}$ of soil or less. In 3 of the 10 samples (\#5, \#12, and \#25), germination was very low, whereas it was very high in the others.

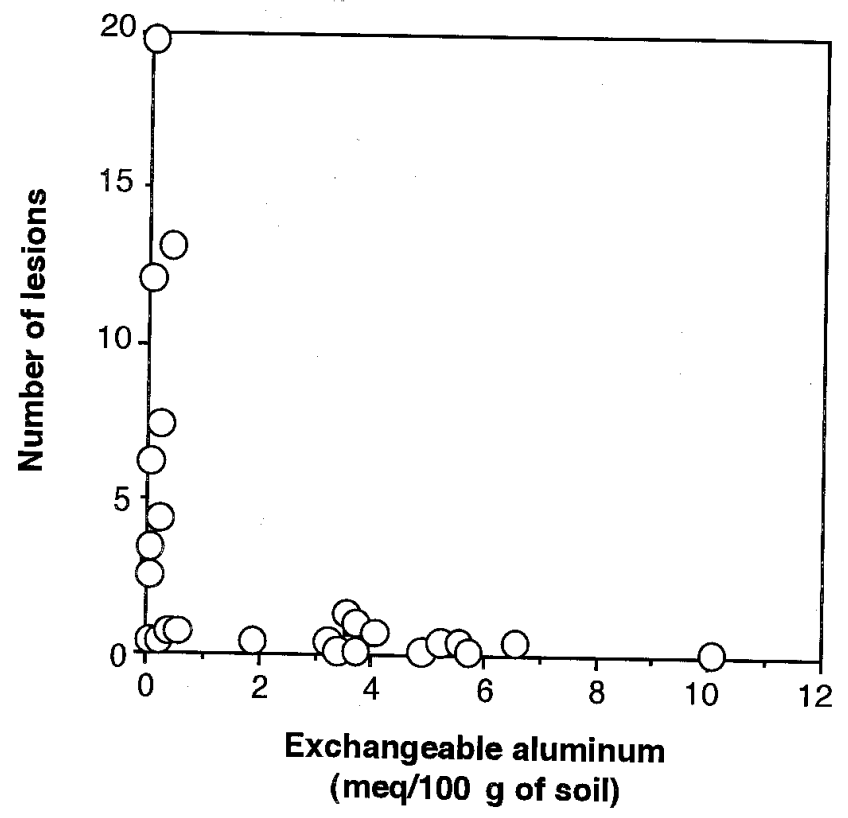

Fig. 2. Severity of bean root rot by Fusarium solani f. sp. phaseoli in soil in relation to soil exchangeable aluminum content. Severity was assessed by the number of lesions on 6-cm bean stem sections buried and incubated for 8 days at $25^{\circ} \mathrm{C}$ in soil samples infested with macroconidia of the fungus at $10^{4}$ per $\mathrm{g}$ of dry soil. 
Disease severity related to soil $\mathrm{pH}$ and exchangeable aluminum. The number of lesions that developed on stem sections was very low in 14 soil samples with $\mathrm{pH} 5.5$ or lower, but was highly variable, between 0 and over 20 , in soil samples with a $\mathrm{pH}$ higher than $5.5(t=3.120, \mathrm{df}=10.0, P=0.0109)$ (Tables 1 and 2$)$. Lesion numbers were also very low in all 15 samples in which exchangeable aluminum was $0.4 \mathrm{meq} / 100 \mathrm{~g}$ of soil or more, whereas they varied very widely, between 0 and more than 20 , in soil samples with a content of $0.3 \mathrm{meq} / 100 \mathrm{~g}$ of soil or less $(t=3.270, \mathrm{df}=9.0$, $P=0.0097$ ) (Fig. 2).

\section{DISCUSSION}

It is apparent that the low disease incidence in 17 soil samples with 1.1 or fewer lesions (and sample \#12) was mainly due to inhibition of macroconidial germination. Macroconidia of $F$. solani $\mathrm{f}$. sp. phaseoli do not require exogenous carbon or nitrogen for germination at low conidial density $(9,10)$ and are not very susceptible to widespread soil fungistasis $(10,30)$. It thus follows that when macroconidia incubated over soil samples at low conidial density fail to germinate, their germination may be inhibited by environmental or edaphic factors.

Inhibition of macroconidial germination in 16 of the 18 soil samples in which macroconidial germination was less than $20 \%$ should be considered due to heat-stable soil factors and, hence, as residual fungistasis (5), since the inhibition was not eliminated by autoclaving (Table 2). Partial or almost complete elimination was observed for the other two samples (\#8 and \#11), but germ tube growth was still inhibited, suggesting that the inhibition was partially residual after autoclaving.

Poor germination at low $\mathrm{pH}$ in many soil samples was not due directly to hydrogen ions, since macroconidia of $F$. solani $\mathrm{f}$. sp. phaseoli have been shown to germinate readily at $\mathrm{pH} 4.0$ or even less in a water solution or on agar media (8). Inhibition of macroconidial germination in these soil samples may only be promoted under acidic conditions, at a $\mathrm{pH}$ less than 5.5 to 5.6. Other than hydrogen ions, aluminum is the only residual factor that has been suggested to inhibit macroconidial germination in acid soils (8). Germination is highly sensitive to aluminum, being inhib- ited at $0.015 \mathrm{meq}$ of aluminum per $100 \mathrm{ml}$ of water solution (8). The current result, that no macroconidial germination was observed in soil samples with higher amounts of exchangeable aluminum, strongly supports the suggestions of Furuya et al. (8) that macroconidial germination may be inhibited by aluminum toxicity in acid soils.

There were four soil samples (\#5, \#12,\#20, and \#25) in which macroconidial germination, germ tube growth of macroconidia, or both was inhibited, even though their contents of exchangeable aluminum were as low as $0.3 \mathrm{meq} / 100 \mathrm{~g}$ of soil or less. Because of such inhibition in the autoclaved soil samples, residual soil factors other than aluminum appear to be involved in the inhibition.

Disease severity was also low in soil samples \#11 and \#19, in which exchangeable aluminum contents were 0.5 and $0.4 \mathrm{meq} / 100 \mathrm{~g}$ of soil, respectively. It appears that disease suppression in these samples resulted from aluminum toxicity to the pathogen, because macroconidial germination in the samples was, most probably, inhibited by residual soil factors. It is not possible to conclude whether the inhibition resulted from aluminum toxicity of the soil samples, since the lowest level of exchangeable aluminum to inhibit macroconidial germination is not known. Biological factors may be involved to some extent in the suppression in soil samples \#8 and $\# 11$, because soil sterilization eliminated, at least partially, the suppression of macroconidial germination.

Swelling of apical cells of macroconidia observed in some soil samples in which germination was inhibited is very similar to that noted for Kitami soil (7) and some other acid soils in Japan (16). In Kitami soil, most swollen cells lose their cytoplasm within several days and finally become lysed without producing chlamydospores $(6,7)$.

The toxicity of soil aluminum to plant roots depends on clay mineralogy and soil $\mathrm{pH}$. Allophanic Andosols have shown little aluminum toxicity to plant roots (26). Nonallophanic Andosols, in which the major clay mineralogy contains $2: 1$ minerals $(25,27,29)$, are toxic when the $\mathrm{pH}$ is less than 5.5 (26). Thus, aluminum that composes non- to paracrystalline (short range order) clay minerals such as allophane and imogolite is not harmful to roots, whereas aluminum adsorbed in permanent charges of the 2:1-type minerals such
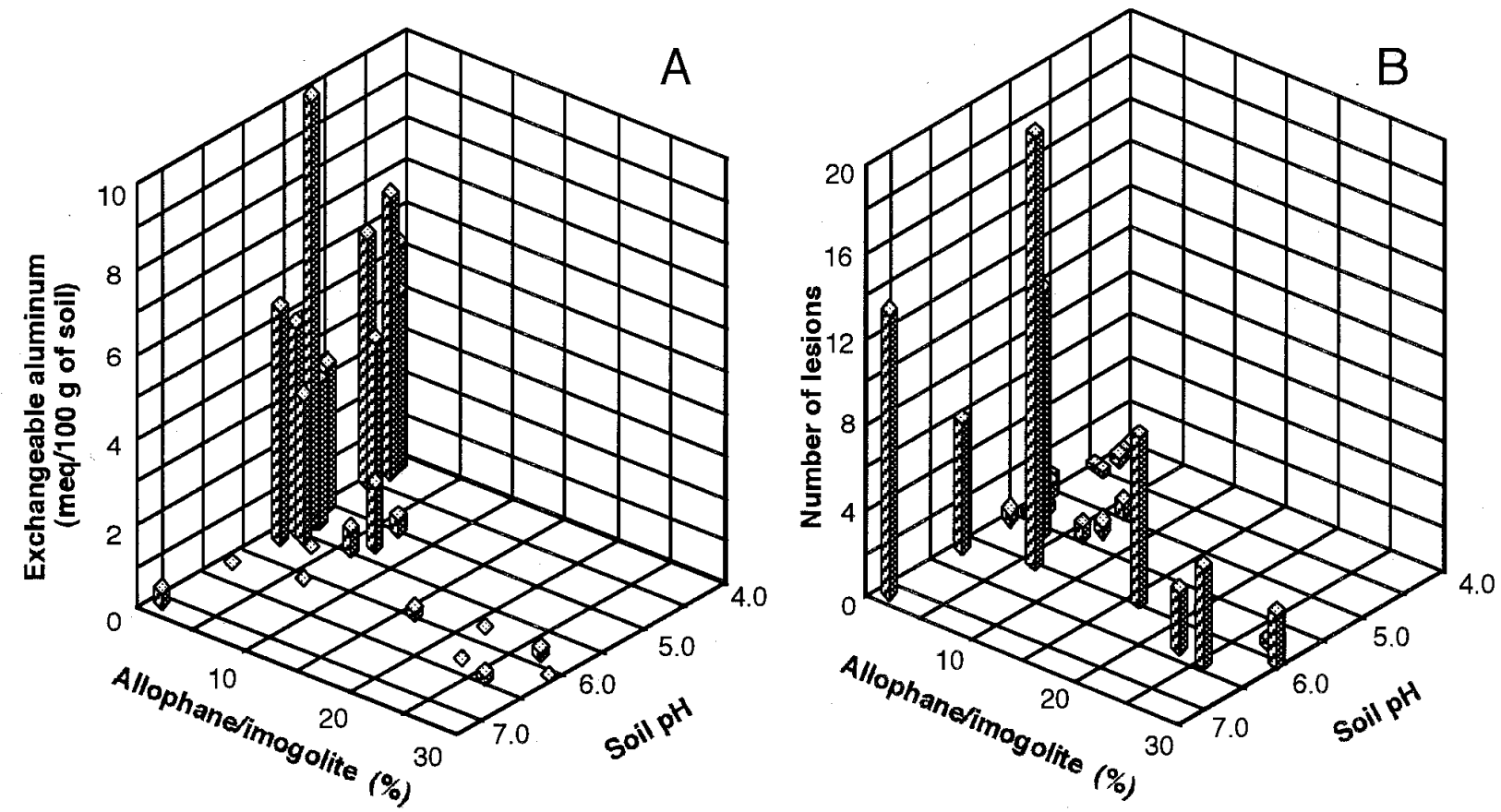

Fig. 3. Effects of clay mineralogy and soil $\mathrm{pH}$ on A, soil exchangeable aluminum content in soil, and $\mathbf{B}$, severity of bean root rot by Fusarium solani f. sp. phaseoli. Severity was assessed by the number of lesions on $6-\mathrm{cm}$ bean stem sections buried and incubated for 8 days at $25^{\circ} \mathrm{C}$ in the soil samples infested with macroconidia of the fungus at $10^{4}$ per $g$ of dry soil. 
as $\mathrm{Al}^{3+}\left(\left[\mathrm{Al}\left(\mathrm{OH}_{2}\right)_{6}\right]^{3+}\right)$ can be quite harmful. This is consistent with our current results on aluminum toxicity to $F$. solani f. sp. phaseoli. Soil samples with a major clay mineralogy of allophane/imogolite contained small amounts of exchangeable aluminum (Fig. 3A), whereas those with a major clay mineralogy of 2:1-type minerals contained more exchangeable aluminum and suppressed lesion development on stem sections by the pathogen (Fig. 3B). The same mechanism should thus be operative in the suppression of the pathogen by soil aluminum as aluminum toxicity to plant roots. Disease incidence is thus closely related to soil mineralogy and soil $\mathrm{pH}$, which regulate the behavior of toxic aluminum of soils; therefore, information on the clay mineralogy and $\mathrm{pH}$ of soils may help predict pathogen establishment or disease incidence in soils.

Andosols are widespread soils, constituting $45.1 \%$ of the total upland farm land in Japan (25), and nonallophanic Andosols are also widely distributed (24). A low disease incidence has been reported in many acid soils of the country (16); therefore, soils in which $F$. solani f. sp. phaseoli is suppressed by aluminum toxicity should be widely distributed throughout the country. Furthermore, since acid soils dominated by 2:1 minerals with permanent negative charges are also distributed widely throughout the world, suppression of soilborne plant pathogens by soil aluminum may be much more widespread than previously considered, as suggested by Meyer and Shew (18).

The incidence of Fusarium root rot of bean was previously considered to be unaffected by soil $\mathrm{pH}$. Based on greenhouse experiments and field surveys in western New York, it was concluded that disease incidence was not affected by hydrogen ion concentration in the soil (3). On the other hand, low disease incidence in acid soils collected from the central part of Honshu island, Japan, was clearly demonstrated in an investigation on the disease incidence in microplots at a single location of different soils artificially infested with an equal population density of the pathogen (16). Moreover, Furuya (6) clearly showed that disease incidence in Kitami soil increased significantly with increases in soil $\mathrm{pH}$. These conflicting results may possibly arise from differences in aluminum behavior in the soils of the two countries. Exchangeable aluminum is rather limited (low) in allophane/ imogolite-dominated soils, while it can be very high in 2:1-type clay-dominated soil. The effects of soil $\mathrm{pH}$ on the ecology of soilborne plant pathogens sensitive to aluminum toxicity should thus be investigated with consideration of toxic aluminum behavior in acid soils containing 2:1-type minerals that carry permanent negative charges.

Aluminum toxicity is a major cause of root injury in many crop plants in acid soil. Bean plants are relatively sensitive to soil acidity, but sensitivity differs considerably among cultivars (11). A very tolerant cultivar tolerates up to $0.4 \mathrm{meq}$ of aluminum per $100 \mathrm{ml}$ of nutrient solution (11). The root rot pathogen $F$. solani f. sp. phaseoli is highly sensitive to aluminum, as mentioned above (8), and is thus quite likely to be more sensitive than some bean varieties.

In the Kitami region of Hokkaido, where the suppressive soil is distributed (7), bean plants have been grown as a major commercial crop for more than 50 years without severe acid soil damage. Bean plants can thus be grown at the concentration of toxic soil aluminum that is low enough so that phytotoxicity does not occur and high enough to ensure that disease incidence is kept within low limits.

\section{ACKNOWLEDGMENTS}

We thank S. Shoji and M. Saigusa, Tohoku University, Sendai, Japan; T. Ono, Iwate Agricultural Special School, Morioka, Japan; and I. Yamada, Kyushu National Agricultural Experiment Station, Nishigoshi, Kumamoto, Japan, for providing soil samples and for valuable comments. We also thank the late T. Ui, Hokkaido University, for critical comments on the manuscript.

\section{LITERATURE CITED}

1. Anonymous. 1976. Glossary of Terms in Soil Science, Revised. Can. Dep. Agric. Ottawa.

2. Benson, D. M. 1993. Suppression of Phytophthora parasitica on Cantharanthus roseum with aluminum. Phytopathology 83:13031308.

3. Burkholder, W. H. 1932. Effect of the hydrogen-ion concentration of the soil on the growth of the bean and its susceptibility to dry root rot. J. Agric. Res. 44:175-181.

4. Davey, C. B., and Danielson, R. M. 1968. Soil chemical factors and biological activity. Phytopathology 58:900-908.

5. Dobbs, C. G., and Gash, M. J. 1965. Microbial and residual mycostasis in soils. Nature 207:1354-1356.

6. Furuya, H. 1982. Studies on Fusarium root rot of bean. Bull. Akita Pref. Coll. Agric. 8:1-46.

7. Furuya, H., Owada, M., and Ui, T. 1979. A suppressive soil of common bean root rot in Kitami district, Hokkaido. Ann. Phytopathol. Soc. Jpn. 45:608-617.

8. Furuya, H., Wakui, A., Takahashi, T., and Ui, T. 1996. Inhibition of macroconidial germination of Fusarium solani f. sp. phaseoli by soil aluminum. Ann. Phytopathol. Soc. Jpn. 62:69-74.

9. Griffin, G. J. 1970. Carbon and nitrogen requirements for macroconidial germination of Fusarium solani: Dependence on conidial density. Can. J. Microbiol. 16:733-740.

10. Griffin, G. J., and Ford, R. H. 1974. Soil fungistasis: Fungus spore germination in soil at spore densities corresponding to natural population levels. Can. J. Microbiol. 20:751-754.

11. Howeler, R. H. 1991. Identifying plants adaptable to low $\mathrm{pH}$ conditions. Pages 885-904 in: Plant-Soil Interactions at Low pH. R. J. Wright, V. C. Baligar, and R. P. Murramann, eds. Kluwer Academic Publishers, Dordrecht, the Netherlands.

12. Johnson, L. F., and Curl, E. A. 1972. Methods for Research on the Ecology of Soil-Borne Plant Pathogens. Burgess Publishing Company, Minneapolis, MN.

13. Ko, W. H., and Hora, F. K. 1972. Identification of an Al ion as a soil fungitoxin. Soil Sci. 113:42-45.

14. Kobayashi, N., and Ko, W. H. 1983. Screening of Rhizoctonia-suppressive soil in Hawaii islands and their mechanism of suppressiveness. Soil Microorg. 25:1-8.

15. Kobayashi, N., and Ko, W. H. 1985. Nature of suppression of Rhizoctonia solani in Hawaiian soils. Trans. Br. Mycol. Soc. 84:691-694.

16. Kobayashi, N., and Komada, H. 1995. Screening of suppressive soils to Fusarium wilt from Kanto, Tozan and Tokai area in Japan, and analysis of their suppressiveness. Soil Microorg. 45:21-32.

17. Lewis, J. A. 1973. Effect of mineral salts on Aphanomyces euteiches and Aphanomyces root rot of peas. Phytopathology 63:989-993.

18. Meyer, J. R., and Shew, H. D. 1991. Soil suppressive to black root rot of burley tobacco, caused by Tielaviopsis basicola. Phytopathology 81:946-954.

19. Meyer, J. R., Shew, H. D., and Harrison, U. J. 1994. Inhibition of germination and growth of Thielaviopsis basicola by aluminum. Phytopathology 84:598-602.

20. Mizuno, N., and Yoshida, H. 1993. Effect of exchangeable aluminum on the reduction of potato scab. Plant Soil 155/156:505-508.

21. Muchovej, J. J., Maffia, L. A., and Muchovej, R. M. C. 1980. Effect of exchangeable soil aluminum and alkaline calcium salts on the pathogenicity and growth of Phytophthora capsici from green pepper. Phytopathology 70:1212-1214.

22. Orellana, R. G., Foy, C. D., and Fleming, A. L. 1975. Effect of soluble aluminum on growth and pathogenicity of Verticillium albo-atrum and Whetzelinia sclerotiorum from sunflower. Phytopathology 65:202205.

23. Parfitt, R. L. 1983. Identification of allophane in Inceptisols and Spodosols. Soil Taxon. News 5:11, 18.

24. Saigusa, M., Matsuyama, N., and Abe, T. 1992. Distribution of allophanic Andosols and nonallophanic Andosols in Japan based on the data of soil survey reports on reclaimed land. Jpn. J. Soil Sci. Plant Nutr. 63: 646-651.

25. Saigusa, M., Matsuyama, N., Honna, T., and Abe, T. 1991. Chemistry and fertility of acid Andisols with special reference to subsoil acidity. Pages 73-80 in: Plant-Soil Interactions at Low pH. R. J. Wright, V. C. Baligar, and R. P. Murramann, eds. Kluwer Academic Publishers, Dordrecht, the Netherlands.

26. Saigusa, M., Shoji, S., and Takahashi, T. 1980. Plant root growth in acid Andosols from northeastern Japan: 2. Exchange acidity $\mathrm{Y}_{1}$ as a realistic measure of aluminum toxicity potential. Soil Sci. 130:242250 .

27. Shoji, S., Ito, T., Saigusa, M., and Yamada, I. 1985. Properties of nonal- 
lophanic Andosols from Japan. Soil Sci. 140:264-277.

28. Shoji, S., Saigusa, M., and Takahashi, T. 1980. Plant root growth in acid Andosols from northeastern Japan: 1. Soil properties and root growth of burdock, barley, and orchard grass. Soil Sci. 130:124-131.

29. Shoji, S., Suzuki, Y., and Saigusa, M. 1987. Clay mineralogical and chemical properties of nonallophanic Andepts from Oregon, USA. Soil Sci. Soc. Am. J. 51:986-990.

30. Steiner, G. W., and Lockwood, J. L. 1969. Soil fungistasis: Sensitivity of spores in relation to germination time and size. Phytopathology 59:1084-1092.

31. Zwarun, A. A., Bloomfield, B. J., and Thomas, G. W. 1971. Effect of soluble and exchangeable aluminum on a soil Bacillus. Soil Sci. Soc. Am. Proc. 35:460-463.

32. Zwarun, A. A., and Thomas, G. W. 1973. Effect of soluble and exchangeable aluminum on Pseudomonas stutzeri. Soil Sci. Soc. Am. Proc. 37:386-387. 